\section{An audit improves the quality of water within the dental unit water lines of general dental practices across the East of England}

\author{
R. A. C. Chate $^{1}$
}

VERIFIABLE CPD PAPER

IN BRIEF
- Demonstrates how clinical audit
can improve standards in cross-
infection control.
- Sufficient details are given for individual
clinicians to replicate the audit in their
own practices.
- American Dental Association and
European Union water quality
standards are given as appropriate
standards to adopt.

\begin{abstract}
Objective To evaluate and improve upon the quality of water emanating from the dental unit waterlines (DUWLs) which supply irrigation for dental handpieces and triple spray syringes in general practice. Design A prospective clinical audit. Setting Seventy-two general dental practices in the East of England. Methods In 2006, 124 dentists initially registered to participate in the audit. By 2007, 72 had begun and by 2008, 68 had completed the project. This involved collecting samples of water discharged from the DUWLs in the dental practices both before the start and mid-way through a morning session. These were tested microbiologically at a United Kingdom Accreditation Service testing laboratory. Interventions Before the audit, 56\% of the DUWLs were reportedly flushed through for 2 minutes at the start of the day, 29\% were purged for 20 seconds in between each patient, 50\% were treated with a wide range of different disinfectant solutions, 44\% were drained down dry at the end of the day and 9\% had no cross-infection control measures applied to them at all. In the audit, 100\% used a disinfectant solution alone, predominantly either Alpron or Sterilox. Main outcome measures The minimum audit standard set was for the water samples to meet the United States' Centers for Disease Control and Prevention (CDC) guideline on the quality of DUWL water, namely that the United States' Environmental Protection Agency (EPA) regulatory standards for drinking water be adopted, in that no more than $5 \%$ of water samples should be contaminated with total coliforms and that they should not have more than 500 colony forming units per $\mathrm{ml}$ (cfu/ml) of heterotrophic water bacteria. However, the participating dentists were encouraged to try and achieve the more stringent European Union (EU) standards for potable (drinking) water, namely for the water samples to have neither Escherichia colinor any other faecal coliforms present and for the aerobic colony count to be less than $100 \mathrm{cfu} / \mathrm{ml}$ at $22^{\circ} \mathrm{C}$ after 72 hours of culturing. Results In the preaudit survey, none of the 72 DUWL water samples were contaminated with E. coli but in five of them (7\%) coliforms were recovered. Only $25 \%$ reached the EU potable water standard, of which $11 \%$ had zero planktonic bacterial contamination. Three percent were above the EU standard but below the CDC guideline/EPA regulatory drinking water standard, while alarmingly, $72 \%$ of them failed to reach this minimum audit standard altogether. However, after the application of a suitable disinfectant for at least a month, the audit revealed that E. coli still remained absent in the water samples taken from the 68 DUWLs that completed the project and in only one (1.5\%) were coliforms recovered. Remarkably, nearly $81 \%$ reached the EU potable water standard, of which 54\% had zero planktonic bacterial contamination, with nearly an additional $6 \%$ reaching the American CDC/EPA standard and with only 13\% failing outright. Conclusions Clinical audit using appropriate DUWL disinfectants can result in the improvement of the quality of water that is discharged through DUWLs, thereby minimising both the risk of cross-infection to vulnerable patients as well as to dental staff chronically exposed to contaminated aerosols.
\end{abstract}

\section{INTRODUCTION}

Biofilms which form within dental unit water lines (DUWLs) do so within a few weeks of each unit's installation and connection to a water supply. ${ }^{1}$ They consist

${ }^{1}$ Consultant Orthodontist, Orthodontic Department, Essex County Hospital, Lexden Road, Colchester, C03 3NB Correspondence to: Mr Robert A. C. Chate

Email:chate@rcsed.ac.uk

Tel: +44 (0)1206744 621; Fax:+44 (0)1206574684

Online article number E11

Refereed Paper - accepted 10 June 2010

DOI: $10.1038 /$ sj.bdj.2010.885

${ }^{\circledR}$ British Dental Journal 2010; 209: E11 mainly of bacteria in a complex communal architecture enveloped in a self-generated glycocalyx polysaccharide slime, which protects the microbes from desiccation, chemical insult, predation and immunological attack. ${ }^{2}$

Most of the micro-organisms are aerobic, gram negative, non-coliform water bacteria which have limited pathogenic potential in immunocompetent people. ${ }^{2}$ DUWL biofilms are typically colonised by Pseudomonas aeruginosa, Legionella pneumophila, non-tuberculous mycobacteria
(NTM) and Escherichia, as well as by oral flora such as Bacteroides, streptococci, actinomycetes, lactobacillii, staphylococci, Veillonella and Candida., Despite the routine use of anti-retraction valves, salivary blood-borne hepatitis B and HIV have been shown experimentally to be sucked back into handpieces and have been recovered distally in dental waterlines. ${ }^{1}$ Concern has been expressed that theoretically this could also occur with prions. ${ }^{5}$

With regard to the existence of legal standards that apply to the quality of 
water emanating from DUWLs, in 1995 the American Dental Association (ADA) recommended that by the year 2000, DUWLs should have no more than 200 colony forming units per $\mathrm{ml}(\mathrm{cfu} / \mathrm{ml})$ in water samples, ${ }^{6}$ the threshold of which had been based on the quality assurance standard established for fluid delivery systems in haemodialysis. In December 2003, the United States' Centers for Disease Control and Prevention (CDC) then issued guidelines, ${ }^{7}$ which recommended that DUWL water should meet the United States' 1999 Environmental Protection Agency regulatory drinking water standards. These stated that no more than 5\% of water samples should be contaminated with total coliforms and that they should not have more than $500 \mathrm{cfu} / \mathrm{ml}$ of heterotrophic water bacteria. ${ }^{8}$ As a consequence, in March 2004 the American Dental Association urged dentists to follow the CDC infection control procedures in general ${ }^{9}$ and by July that year, to specifically adopt the DUWL CDC recommendations. ${ }^{10}$

Separately, the European Union (EU) has set a standard for potable (drinking) water, namely the absence of Escherichia coli or any other faecal coliforms, and with an aerobic colony count of less than $100 \mathrm{cfu} /$ $\mathrm{ml}$ after 72 hours of culturing at $22^{\circ} \mathrm{C}$, or of $20 \mathrm{cfu} / \mathrm{ml}$ after 24 hours of culturing at $37^{\circ} \mathrm{C} .{ }^{11}$ (The former value taken at 72 hours is the one that defines the level of water contamination while the latter taken at 24 hours is used as an initial screening to more quickly estimate whether the final result is likely to be so high that a significant risk to public health needs to be urgently averted, for example, as in the case of passenger carrying ships and aircraft).

Since then, a number of studies have surveyed the compliance with these targets among general dental practices, both in the $\mathrm{UK}^{12}$ and in Europe. ${ }^{13,14}$ Out of 55 English dental practices, 95\% of their DUWL levels of contamination were found to have exceeded the EU standard for potable water, with 83\% failing to meet the 1995 ADA DUWL recommendation..$^{12}$ In Europe, in one study among 237 dental practices across seven countries, 51\% exceeded the 1995 ADA guideline, ${ }^{13}$ while in another involving a different 134 units, 64\% also failed. ${ }^{14}$
In absolute terms, the mean levels of contamination reported for European dental practices have ranged from 32-320 cfu/ $\mathrm{ml},{ }^{13}$ while for those in Great Britain and Ireland the levels have been much higher, at around 2,500 $\mathrm{cfu} / \mathrm{ml}^{12,15}$ and $66,000 \mathrm{cfu} / \mathrm{ml}^{16,17}$

Despite the general prevalence of such high recordings, there still remains no scientific evidence that DUWL biofilms represent a public health risk. ${ }^{10}$ It has been postulated that this could either be due to the true absence of disease transmission, or because of the difficulty of establishing epidemiological links between infections with extended incubation times and antecedent dental procedures. ${ }^{18}$

Nevertheless, immunodeficient patients are more susceptible to infection from waterborne opportunistic pathogens, ${ }^{1,19,20}$ and with NTM being recovered from 5\% of English general dental practice DUWLs, ${ }^{12}$ and the mean levels of NTM contamination of $365 \mathrm{cfu} / \mathrm{ml}$ among 21 German dental office DUWLs being 400 times that of the local water supply, ${ }^{21}$ it is not surprising that others have implicated a dental origin as the source of some patients' NTM infections. ${ }^{22,23}$

Legionella pneumophila, the organism responsible for legionnaires disease, ${ }^{2}$ has also been recovered from the DUWLs of $1 \%$ of European general dental practices, ${ }^{13}$ up to $2 \%$ of British dental practices ${ }^{12,24}$ and between 2\% and 8\% of American dental offices. ${ }^{25,26}$ Higher recovery rates have been associated with water samples taken from dental hospitals and other large institutions, specifically $21.8 \%$ from Italian private and public institutions ${ }^{27}$ and 25\% from a London dental hospital. ${ }^{28}$

Although L. pneumophila is not the dominant component in dental unit water, heavy exposure to species of Legionella should be investigated as a potential health risk for both dental personnel and their immunocompromised patients. ${ }^{25}$ Indeed, $20 \%$ of American ${ }^{29}$ and 34\% of Austrian dental personnel have been found to have significantly higher serological levels of antibodies against L. pneumophila as compared to controls, ${ }^{30}$ although this has not been found to be the case among a sample of 266 UK dentists. ${ }^{24}$

Nevertheless, the death of a Californian dentist with legionellosis seems probably attributable to his exposure of the high levels of Legionella spp. found in his dental operatory, with the most likely source being the contaminated aerosols from his dental units. ${ }^{25}$

Another potential risk to clinical staff from contaminated aerosols relates to the development of asthma. It is known that endotoxin exposure exacerbates asthma, and that Gram-negative bacteria which contain cell wall endotoxins predominate the flora in DUWLs. ${ }^{2,31}$ Nevertheless, while one study of a group of 266 UK dentists has not found a significant association between the two in general, among a subset of 33 dentists who reported developing asthma since they started their dental training, exposure to passive smoking, and separately, exposure to aerobic colony counts at $37^{\circ} \mathrm{C}$ of greater then $200 \mathrm{cfu} / \mathrm{ml}$ were both found to be significant. ${ }^{17}$

The aim of this study was therefore to evaluate the quality of water emanating from the DUWLs which supplied irrigation for the dental handpieces and triple spray syringes in general dental practices across the East of England and to undertake an audit to improve upon it.

\section{METHODS}

In 2006 all of the general dental practitioners in the East of England were notified of an opportunity to take part in a regional audit on cross-infection control. This required them to attend one of the Eastern Deanery's 14 postgraduate medical centres, where on different dates throughout the year they could register. As part of their induction, they initially had to answer a questionnaire on (i) their current knowledge of water quality standards, (ii) the type and age of the dental units they worked with and (iii) what, if any, cross-infection protocols they currently applied to their DUWLs. They were then given an introductory lecture on the topic that also included specific details and instructions on how to participate in the audit.

\section{Water sampling}

Each of the participating dentists were asked to collect a DUWL water sample on any week day apart from a Monday. This was to maintain consistency of the method applied to all of the practices where the potential for higher levels of contamination after a weekend 


\begin{tabular}{|c|c|c|c|}
\hline & Options & Number & Percent \\
\hline \multirow[t]{2}{*}{ Origin of DUWL water } & Direct from mains supply & 8 & $6 \%$ \\
\hline & Independent water bottle & 117 & $94 \%$ \\
\hline \multirow{3}{*}{$\begin{array}{l}\text { Type of water used } \\
\text { in the DUWL }\end{array}$} & Mains tap water & 43 & $34 \%$ \\
\hline & Distilled & 71 & $57 \%$ \\
\hline & Sterile & 11 & $9 \%$ \\
\hline \multirow{5}{*}{$\begin{array}{l}\text { Measures taken to } \\
\text { maintain DUWL } \\
\text { water quality }\end{array}$} & 2 minute flush at the start of the day & 70 & $56 \%$ \\
\hline & 20-second purges after each patient & 36 & $29 \%$ \\
\hline & Disinfectant solution used & 62 & $50 \%$ \\
\hline & Drain down DUWLs dry at the end of the day & 55 & $44 \%$ \\
\hline & None taken at all & 11 & $9 \%$ \\
\hline \multirow{2}{*}{$\begin{array}{l}\text { Ever had DUWL } \\
\text { water tested? }\end{array}$} & Yes & 1 & $1 \%$ \\
\hline & No & 124 & $99 \%$ \\
\hline
\end{tabular}

of water stagnation within the water lines could otherwise skew the results in comparison.

To test the water on each occasion, $250 \mathrm{ml}$ samples were discharged from the DUWLs just before the start and mid-way through the chosen morning session. These were collected aseptically in sterile bottles containing $0.1 \mathrm{~g}$ of sodium thiosulphate that would neutralise either any residual chlorine or, if relevant, any disinfectant left in the water. ${ }^{17,32,33}$

The samples were stored in each practice's refrigerator until transfer to the laboratory using a cool box could be made within 6 hours of collection. This is recommended in order to prevent bacterial counts from increasing within the water samples after their collection through prolonged stagnation at ambient temperatures.

The processing of the samples was undertaken in a United Kingdom Accreditation Service testing laboratory, and they were analysed not only for aerobic colony counts at $22^{\circ} \mathrm{C}$ after 72 hours and $37^{\circ} \mathrm{C}$ after 24 hours, using a standard pour plate method as outlined in detail elsewhere, ${ }^{15,33,34}$ but also for the possible presence of coliforms using a recognised technique. ${ }^{35}$

\section{Audit standards}

The standards that were set for the audit were that as a minimum, the samples should at least meet the United States' CDC guideline/EPA regulatory drinking water standard $^{7,8}$ as endorsed by the ADA,,${ }^{9,10}$ but preferably that they should reach the EU standards for potable (drinking) water. ${ }^{11}$

\section{Audit protocol}

In order to enable comparative evaluations to be made throughout the study, the dentists were instructed to complete both the pre-audit survey and the audit assessments of their DUWL levels of contamination, regardless of whether their pre-audit water samples should be found to already comply with either of the suggested audit quality standards. If they did not, they were requested to begin by using an initial shock purge of preferably either Alpron or Sterilox disinfectants, followed by at least 1 month of continuous application before their DUWLs were retested, as recommended by the respective manufacturers. For those units whose pre-audit levels of DUWL contamination were found to be already compliant, the dentists were asked either to continue with their existing disinfection regimes for at least a further month before retesting for the audit, or to convert to using either Alpron or Sterilox if they preferred to instead.

\section{RESULTS}

\section{Knowledge of water quality standards}

One hundred and twenty-four dentists initially registered to participate in the audit in 2006. With regard to their prior knowledge of water quality standards, while $26 \%$ of them reported that they were aware of the existence of the 1995 ADA DUWL water quality guideline, overall, only 5\% knew what it was. Forty-eight percent also reported that they knew the EU applied quality standards to potable water but overall, only $4 \%$ knew what it was.

\section{Dental unit features and pre-audit cross-infection control measures}

Of the 125 dental units that had been listed by the original 124 registered dentists, a wide selection of different manufacturers and makes had been recorded, with Belmont being the most popular for about a third of the participants followed by A-dec and Kavo for about a tenth of them each. The age of the chairs ranged from 1 to 25 years with a mean of 14 years (SD 4.8), a median of 6.5 years and a mode of 10 years. In relation to the DUWL cross infection procedures that either were or were not applied before the audit, Table 1 shows that $94 \%$ of the units had an independent reservoir with the source of water in 34\% being tap water, 57\% using distilled water and 9\% using sterile water.

Fifty-six percent of the DUWLs were reportedly flushed through for 2 minutes at the start of the day, 29\% were purged for 20 seconds in between each patient, $50 \%$ were treated with a wide range of different disinfectant solutions, 44\% were drained dry at the end of the day, while 9\% of the units had no cross-infection control measures applied to them at all and only one dental unit had ever been formally tested for its DUWL water quality.

\section{Loss of audit participants}

By 2007, 72 of the originally registered dentists had begun the pre-audit process of evaluating their DUWLs. Of the remaining 53 dentists, 40\% gave no reason as to why they had decided not to take part in the audit while the majority of the remainder cited that it would be either too inconvenient or time consuming.

\section{Pre-audit and audit protocol compliance}

By the end of 2008, 68 of the dentists had completed the audit and in relation to compliance with the water collection protocols, $92 \%$ of the water samples were 


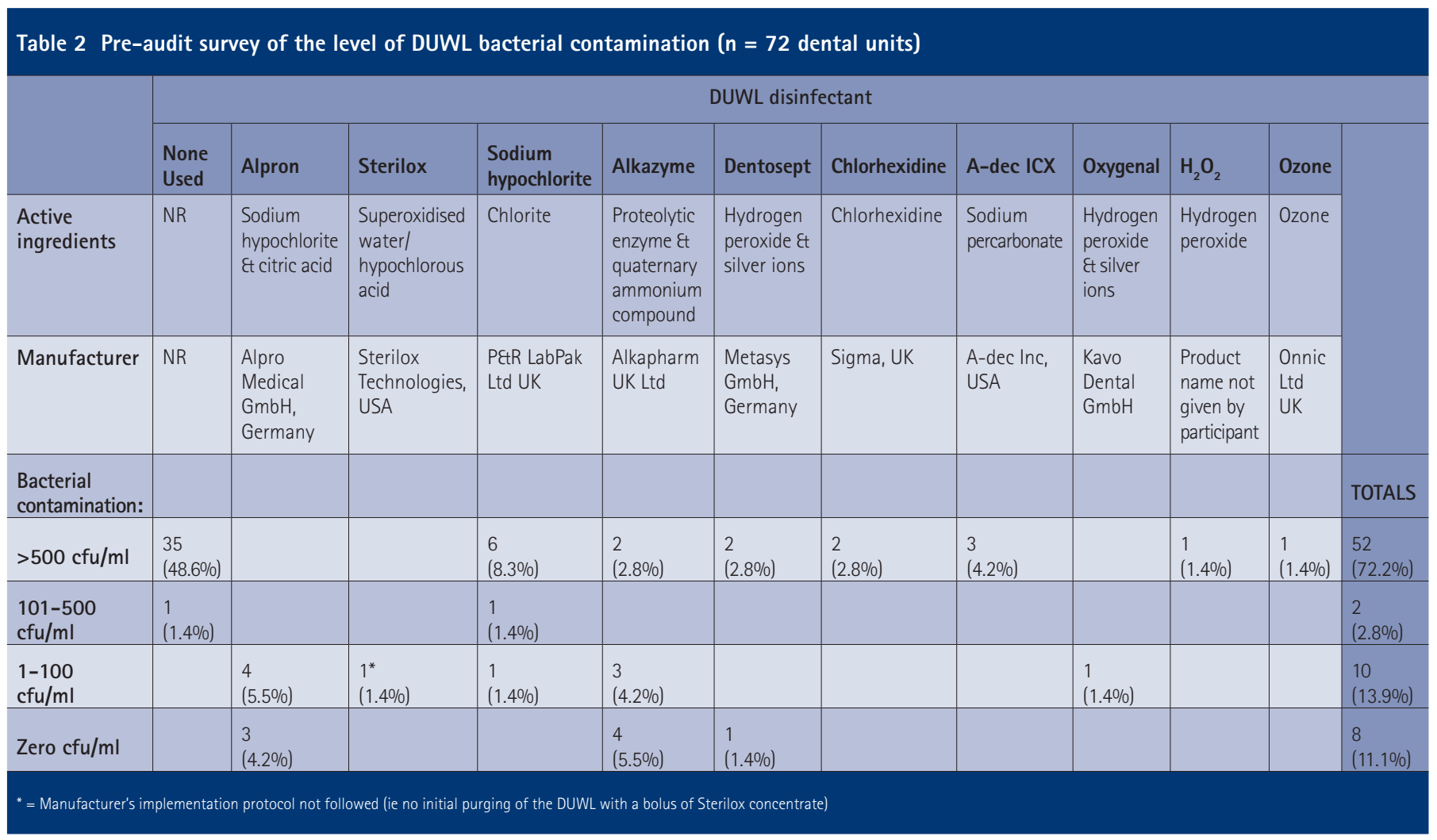

delivered to the laboratory for analysis if not within 6 hours, then at least by the same day during the pre-audit survey and this was similarly the case for $97 \%$ of the water samples during the audit. Monday, as a water sample collection day, had been avoided entirely during the pre-audit survey but had occurred on two occasions during the audit.

\section{Pre-audit survey findings}

Table 2 shows that half of the 72 dental units during the pre-audit survey had never had their DUWLs disinfected while the other half had had a wide range of disinfectants applied. This table also shows that bacterial contamination of the water in the DUWLs predominated, with three quarters of them failing to reach the EU water quality guideline. This included all of the DUWLs that had not been disinfected as well as a half of those that had. Two units (one disinfected and one untreated) were below the CDC/EPA standard of $500 \mathrm{cfu} /$ $\mathrm{ml}$ but both were above the 1995 ADA standard of $200 \mathrm{cfu} / \mathrm{ml}$.

Only a quarter of all the units were below the EU potable water quality standard, of which $11 \%$ had zero planktonic bacterial contamination. For all of these 18 successful dental units, Alpron and Alkazyme at this pre-audit stage of the study were the

Table 3 Pre-audit levels of DUWL bacterial contamination for pre-clinic start water samples ( $n=72$ units)

\begin{tabular}{|c|c|c|c|c|}
\hline & Mean & SD & $\begin{array}{l}\text { Number of units } \\
\text { with zero cfu/ml }\end{array}$ & $\begin{array}{l}\text { Number of units with } \\
>300,000 \mathrm{cfu} / \mathrm{ml}\end{array}$ \\
\hline Escherichia coli/100 ml & 0 & 0 & NR & NR \\
\hline Total coliforms/100 ml & $0.5^{*}$ & 2.0 & NR & NR \\
\hline $\begin{array}{l}\text { Aerobic colony count } / \mathrm{ml} \\
\text { at } 22^{\circ} \mathrm{C} \text { for } 72 \mathrm{hrs}\end{array}$ & 60,892 & 106,462 & $9(12.5 \%)$ & $9(12.5 \%)$ \\
\hline
\end{tabular}

Table 4 Pre-audit levels of DUWL bacterial contamination for mid-session water samples ( $n=72$ units)

\begin{tabular}{|c|c|c|c|c|}
\hline & Mean & SD & $\begin{array}{l}\text { Number of units } \\
\text { with zero cfu/ml }\end{array}$ & $\begin{array}{l}\text { Number of units with } \\
>300,000 \mathrm{cfu} / \mathrm{ml}\end{array}$ \\
\hline Escherichia coli/100 ml & 0 & 0 & NR & NR \\
\hline Total coliforms $/ 100 \mathrm{ml}$ & $3.2^{*}$ & 23.8 & NR & NR \\
\hline $\begin{array}{l}\text { Aerobic colony count } / \mathrm{ml} \\
\text { at } 22^{\circ} \mathrm{C} \text { for } 72 \mathrm{hrs}\end{array}$ & 57,398 & 109,886 & $12(16.7 \%)$ & $9(12.5 \%)$ \\
\hline
\end{tabular}

two disinfectant products that had been the most commonly used.

Table 3 provides data on the levels of DUWL bacterial contamination of the water samples that were taken in the morning before the start of the session. These show that while none of the 72 dental units had been contaminated with $E$. coli, five (7\%) contained traces of coliforms which can be indicative of possible faecal contamination.
The mean aerobic colony count taken after 72 hours of culturing at $22^{\circ} \mathrm{C}$ for these water samples was $60,892 \mathrm{cfu} / \mathrm{ml}$ (SD 106,462 cfu/ml). Nine (12.5\%) of the 72 dental units had zero planktonic bacterial contamination while another nine $(12.5 \%)$ were so heavily contaminated that the ability of the laboratory system to continue accurately counting them above $300,000 \mathrm{cfu} / \mathrm{ml}$ had been overwhelmed. 


\begin{tabular}{|c|c|c|c|c|c|c|c|c|c|}
\hline & \multicolumn{9}{|c|}{ DUWL disinfectant } \\
\hline & None used & Alpron & Sterilox & $\begin{array}{l}\text { Sodium } \\
\text { hypochlorite }\end{array}$ & Alkazyme & Dentosept & $\begin{array}{l}\text { EDTA + sodium } \\
\text { hypochlorite + Oxygenal }\end{array}$ & Oxygenal & \\
\hline $\begin{array}{l}\text { Active } \\
\text { ingredients }\end{array}$ & NR & $\begin{array}{l}\text { Sodium } \\
\text { hypochlorite } \\
\text { \&t citric acid }\end{array}$ & $\begin{array}{l}\text { Superoxidised } \\
\text { water/ } \\
\text { hypochlorous } \\
\text { acid }\end{array}$ & Chlorite & $\begin{array}{l}\text { Proteolytic } \\
\text { enzyme \& } \\
\text { quaternary } \\
\text { ammonium } \\
\text { compound }\end{array}$ & $\begin{array}{l}\text { Hydrogen } \\
\text { peroxide \& } \\
\text { silver ions }\end{array}$ & $\begin{array}{l}\text { Ethylenediaminetetraacetic } \\
\text { acid }+ \text { chlorite }+ \text { hydrogen } \\
\text { peroxide \& silver ions }\end{array}$ & $\begin{array}{l}\text { Hydrogen } \\
\text { peroxide \& } \\
\text { silver ions }\end{array}$ & \\
\hline Manufacturer & NR & $\begin{array}{l}\text { Alpro Medical } \\
\text { GmbH, } \\
\text { Germany }\end{array}$ & $\begin{array}{l}\text { Sterilox } \\
\text { Technologies, } \\
\text { USA }\end{array}$ & $\begin{array}{l}\text { P\&tR LabPak } \\
\text { Ltd UK }\end{array}$ & $\begin{array}{l}\text { Alkapharm } \\
\text { UK Ltd }\end{array}$ & $\begin{array}{l}\text { Metasys } \\
\text { GmbH, } \\
\text { Germany }\end{array}$ & $\begin{array}{l}\text { Kavo Dental GmbH for } \\
\text { Oxygenal }\end{array}$ & $\begin{array}{l}\text { Kavo Dental } \\
\text { GmbH }\end{array}$ & \\
\hline $\begin{array}{l}\text { Bacterial } \\
\text { contamination: }\end{array}$ & & & & & & & & & TOTALS \\
\hline$>500 \mathrm{cfu} / \mathrm{ml}$ & $1^{*}(1.5 \%)$ & $6(8.8 \%)$ & $1(1.5 \%)$ & $1(1.5 \%)$ & & & & & $9(13.2 \%)$ \\
\hline $101-500 \mathrm{cfu} / \mathrm{ml}$ & & $4(5.9 \%)$ & & & & & & & $4(5.9 \%)$ \\
\hline $1-100 \mathrm{cfu} / \mathrm{ml}$ & & 14 (20.6\%) & $3(4.4 \%)$ & & & & $1(1.5 \%)$ & & $18(26.5 \%)$ \\
\hline Zero cfu/ml & & 28 (41.2 \%) & $5(7.4 \%)$ & & $2(2.9 \%)$ & $1(1.5 \%)$ & & $1(1.5 \%)$ & $37(54.4 \%)$ \\
\hline
\end{tabular}

Table 4 gives identical E. coli and coliform data for the mid-session water samples that had been collected. The mean aerobic colony count taken after 72 hours of culturing at $22^{\circ} \mathrm{C}$ for these water samples had dropped slightly to $57,398 \mathrm{cfu} / \mathrm{ml}$ (SD $109,886 \mathrm{cfu} / \mathrm{ml})$ while $12(16.7 \%)$ of the 72 dental units had zero planktonic bacterial contamination and nine (12.5\%) had colony counts in excess of $300,000 \mathrm{cfu} / \mathrm{ml}$.

\section{Audit results}

Table 5 shows that of the 72 dental units that had had their DUWLs initially tested, 68 of them remained in the study and all had been properly disinfected as per the audit protocol for the minimum requisite period of a month before being retested, bar one. While only a handful of practitioners continued to use their pre-audit choice of DUWL disinfectant, the majority had converted primarily to the use of Alpron and to a lesser extent to the use of Sterilox.

As a consequence, remarkably over four fifths of them (80.9\%) reached the EU potable water standard, of which over a half of them (54.4\%) had zero planktonic bacterial contamination. Four units (5.9\%), all of which had been disinfected with Alpron, were below the CDC/EPA standard of $500 \mathrm{cfu} / \mathrm{ml}$ but were above the 1995 ADA standard of $200 \mathrm{cfu} / \mathrm{ml}$, while only nine units (13.2\%) still failed outright to reach any DUWL water quality standard.

Table 6 provides the data on the levels

Table 6 Audit levels of DUWL bacterial contamination for pre-clinic start water samples ( $n=68$ units)

\begin{tabular}{l|l|l|l|l} 
& Mean & SD & $\begin{array}{l}\text { Number of units (\%) } \\
\text { with zero cfu/ml }\end{array}$ & $\begin{array}{l}\text { Number of units (\%) } \\
\text { with }>300,000 \mathrm{cfu} / \mathrm{ml}\end{array}$ \\
\hline Escherichia coli/100 $\mathrm{ml}$ & 0 & 0 & NR & NR \\
\hline Total coliforms $/ 100 \mathrm{ml}$ & $0.1^{*}$ & 0.6 & NR & NR \\
\hline $\begin{array}{l}\text { Aerobic colony count } / \mathrm{ml} \\
\text { at } 22^{\circ} \mathrm{C} \text { for } 72 \mathrm{hrs}\end{array}$ & 3,338 & 15,823 & $47(69.1 \%)$ & 0 \\
* One unit had coliform contamination of its DUWL water: (5/100 ml). Indicative but not absolute evidence of faecal contamination \\
\hline
\end{tabular}

Table 7 Audit levels of DUWL bacterial contamination for mid-session water samples ( $n=68$ units)

\begin{tabular}{l|l|l|l|l} 
& Mean & SD & $\begin{array}{l}\text { Number of units (\%) } \\
\text { with zero cfu/ml }\end{array}$ & $\begin{array}{l}\text { Number of units (\%) } \\
\text { with }>300,000 \mathrm{cfu} / \mathrm{ml}\end{array}$ \\
\hline Escherichia coli/100 ml & 0 & 0 & NR & NR \\
\hline Total coliforms/100 ml & $0.1^{*}$ & 0.5 & NR & NR \\
\hline $\begin{array}{l}\text { Aerobic colony count/ml } \\
\text { at } 22^{\circ} \mathrm{C} \text { for } 72 \mathrm{hrs}\end{array}$ & 1,150 & 3,845 & $41(60.3 \%)$ & 0 \\
* One unit had coliform contamination of its DUWL water: (4/100 ml). Indicative but not absolute evidence of faecal contamination
\end{tabular}

of DUWL bacterial contamination of the audit water samples that were taken in the morning before the start of the session. These show that all of the 68 dental units had remained uncontaminated by $E$. coli, with only one (1.5\%) persisting with traces of coliforms in the DUWL water. The mean aerobic colony count taken after 72 hours of culturing at $22^{\circ} \mathrm{C}$ for these water samples had dramatically reduced to $3,338 \mathrm{cfu} / \mathrm{ml}$ (SD 15,823 cfu/ml). Forty-seven (69.1\%) of the 68 dental units had zero planktonic bacterial contamination while none of them had heavy levels of contamination above $300,000 \mathrm{cfu} / \mathrm{ml}$.

Table 7 gives identical E. coli and coliform data for the mid-session water samples that had been collected for the audit. The mean aerobic colony count taken after 72 hours of culturing at $22^{\circ} \mathrm{C}$ for these water samples had dropped further to $1,150 \mathrm{cfu} / \mathrm{ml}$ (SD 3,845 cfu/ml) while 41 (60.3\%) of the 68 dental units had zero planktonic bacterial contamination and still none had colony counts in excess of $300,000 \mathrm{cfu} / \mathrm{ml}$. 


\section{Dental units requiring additional cycles of post-audit DUWL disinfection}

Of the 13 out of 68 audited dental units that failed to reach the audit's EU DUWL water quality guideline after the furst cycle of being purged and then disinfected for a month, ten dentists opted to subsequently re-expose their dental units to another cycle of purging and disinfection for at least a further month before their DUWL water samples were retested. Of these, eight continued to use Alpron, one continued to use Sterilox and one continued to use sodium hypochlorite plus hydrogen peroxide (Table 8). As a consequence, of the eight dental units that were re-disinfected with Alpron, two of them reached zero levels of bacterial contamination, one met the 1995 ADA DUWL quality standard and two met the EU potable water standard. For the remaining three units using Alpron, two still failed outright to reach the audit standard for either the pre-clinic or midtreatment session water samples, while one only reached the EU standard for the mid-treatment session water sample. For the other two dentists who continued to use either sodium hypochlorite plus hydrogen peroxide or Sterilox during the second cycle of DUWL disinfection, both of their dental units still failed to reach the audit standard.

At this point, three of the four dentists whose dental units still remained noncompliant decided to re-expose their units to a third cycle of DUWL disinfection in the hope of reaching compliance with the audit standard. This included the failed user of Sterilox, one of the two failed users of Alpron and the Alpron user who only reached the 1995 ADA DUWL guideline but not the EU standard (Table 8). As a consequence, the 1995 ADA compliant Alpron user's dental unit reached zero levels of DUWL contamination, the failed Alpron user's dental unit reached the EU standard but unfortunately, the Sterilox user's DUWLs still remained non-compliant.

\section{DISCUSSION}

That 94\% of the dental units had an independent water bottle reservoir meant that the vast majority of the DUWLs would be amenable to being audited following disinfection (Table 1). With 75\% of the dental units failing to reach the EU DUWL water

\begin{tabular}{|c|c|c|c|c|}
\hline \multirow{2}{*}{$\begin{array}{l}\text { Number of additional } \\
\text { purges delivered }\end{array}$} & \multicolumn{4}{|c|}{ Disinfectant used and number of dental units re-treated } \\
\hline & Alpron & Sterilox & $\begin{array}{l}\text { Sodium hypochlorite + } \\
\text { hydrogen peroxide }\end{array}$ & $\begin{array}{l}\text { Total number of dental } \\
\text { units retreated }\end{array}$ \\
\hline 1 & 8 & 1 & 1 & 10 \\
\hline 2 & 2 & 1 & & 3 \\
\hline
\end{tabular}

quality guideline during the pre-audit survey (Table 2), even though the majority of participants had used either distilled or sterile water as the irrigant for their units or had employed a range of physical interventions to cleanse their waterlines, this study confirms what others have reported, namely that neither the choice of water ${ }^{36,37}$ nor the flushing through ${ }^{38}$ or drying of the DUWLs makes an acceptable difference in the levels of bacterial contamination. ${ }^{39}$ Indeed, others have also shown that flushing fails to reduce DUWL microbial contamination by anything more than $9 \% .{ }^{40}$ Instead, paradoxically, bacterial counts can increase as and when portions of the biofilm detach from the lining of the tubes and slough off into the water., ${ }^{2,41,42}$

Even though DUWL biofilm formation generally occurs within two weeks of a new dental unit's commissioning, ${ }^{1}$ common sense would seem to indicate that the age of a unit would have a bearing on its level of contamination. While the majority of the dental units in this audit were 10 years old, a previous study has found no evidence to suggest that the age of a unit has any influence on the microbiological quality of its water. ${ }^{15}$

In contrast, research has shown that levels of contamination appear to be related to different models of dental units, even in those present in the same department with the same water supply and virtually identical clinical usage. ${ }^{28}$ As such, while the testing of Belmont units predominated in this audit, there were still a wide range of other different manufacturers and makes of dental units that were tested which could have made this an important variable.

Of all the dentists who were asked not to collect their DUWL samples on a Monday morning in order to potentially avoid a prolonged period of water stagnation over the weekend giving rise to higher levels of bacterial contamination, only two failed to comply during the audit stage of water collection. This could have had an adverse affect on their individual DUWL readings because one of them had a level of contamination that was twice as high as the 1995 ADA guideline while the other had one that was 500 times higher.

Again, getting the water samples to the laboratory for analysis within 6 hours, if not the same day, is important for similar reasons. While the majority of them were delivered in time, of the six DUWL samples from the pre-audit survey that were delivered the next day, only one of them failed to reach the 1995 ADA DUWL guideline. Of the other five samples, one had zero bacterial contamination and the remaining four had levels that met the EU standard. Equally, for the two dental units whose audit water samples were delivered to the laboratory the following day, one had a level of DUWL contamination that was above the 1995 ADA guideline while the other one was below.

That 75\% of the dental units initially failed to deliver water whose quality met the 1995 ADA guideline (Table 2) is very similar to the findings of other studies from the UK and Europe, where between 51\% and $83 \%$ of dental units have previously failed. ${ }^{12-14}$ In addition, the mean levels of DUWL contamination in this study's preaudit survey (Tables 3 and 4) were found to be as alarmingly high as the highest recordings previously published for British and Irish dental units. ${ }^{16,17}$

For the purposes of the study, each unit had had two samples of water collected on every test occasion, in order to measure what affect both overnight DUWL stagnation and separately the flushing through of the lines during normal clinical use might have had on the levels of microbial contamination. One study has shown that while the 1995 ADA guideline cannot be reached even with 4 minutes of continuous flushing of the dental unit waterlines, this process can produce a statistically significant reduction in planktonic bacteria at 
each time interval, compared to baseline and between each time interval. ${ }^{38}$ The slight reduction in the mean levels of DUWL contamination between the pre-start and midsession samples from the pre-audit survey stage of this study (Tables 3 and 4), as well as the halving of the mean readings taken between the pre-start and mid-session samples during the audit stage (Tables 6 and 7) would seem to bear this out.

It was remarkable that as a consequence of the application of a creditable disinfection regime, the audit resulted in a complete reversal of the proportions of those dental units that had previously failed versus those that had reached the minimum DUWL water quality audit standard (Table 5). That 19\% of this audit's 68 dental units that had been used under realistic general dental practice conditions had failed to reach the 1995 ADA DUWL guideline after one cycle of disinfection is comparable with the findings from a previous study where $17 \%$ of 134 dental units across seven European countries had also failed under similar circumstances. ${ }^{14}$

Nevertheless, that the majority of noncompliant dental units reached the minimum audit standard after a second cycle of DUWL disinfection was encouraging, but that some remained unacceptably contaminated even after a third cycle of disinfection was both disappointing and worrying (Table 8). Overall, these findings only highlight the importance of why dentists should not simply rely on the performance claims made by a manufacturer regarding the efficacy of their DUWL disinfectant product once installed, but rather to have all their DUWL water samples subsequently tested and thereafter periodically checked by a United Kingdom Accreditation Service testing laboratory instead.

of all the disinfectants which can be used inside DUWLs, experimentally Alpron, Sterilox, sodium hypochlorite, and Bio 2000 have been shown to have the ability to completely eliminate the total viable counts of bacteria in the water. In descending order, these four products have also been shown to reduce the biofilm coverage within DUWL tubes by a variable amount of 100\%, 99\%, 94\%, and $53 \%$ respectively. ${ }^{40}$

For Alpron, Sterilox and Bio 2000, these experimental findings have been borne out by both a couple of clinical studies ${ }^{32,34}$ and an audit ${ }^{43}$ while more latterly, another study has additionally shown Dentosept and Oxygenal to be very effective DUWL disinfectants as well. ${ }^{14}$ As such, with a reasonable number of effective DUWL disinfection systems now available, it would be difficult to justify the continued use of untreated dental unit water containing bacterial counts greater than those recommended by the EU hereafter. ${ }^{32}$

Indeed, notwithstanding the Health and Safety legal requirement for general dental practice employers to manage the risk of Legionnaires disease from any source of their premises' water ${ }^{1,44}$ or from a self-interest perspective of protecting the health of oneself and the other members of the dental team from the consequences of chronic exposure to contaminated aerosols, ${ }^{17}$ using heavily contaminated water from a dental unit could ultimately expose a clinician to a variety of legal proceedings. ${ }^{45}$

Some might argue that this is only of relevance for those currently involved in treating medically compromised patients within specialist centres, but there is no doubt that as the proportions of the UK population affected by either cancer or profound disability continue to increase by about $1 \%$ each year, the dilemma regarding service delivery will most likely only be resolved by general dental practitioners becoming more involved in providing a service to such patients within their own practices. ${ }^{46}$

\section{CONCLUSIONS}

Clinical audit using appropriate DUWL disinfectants can improve upon the quality of water that is discharged through the majority of general practice DUWLs, thereby minimising both the risk of cross-infection to vulnerable patients as well as to dental staff chronically exposed to contaminated aerosols. However, for a minority of dental units, more than one cycle of disinfection may need to be delivered in order to achieve an acceptable standard of water quality.

My thanks to all of the dentists who participated in this audit, to Martin Lodge, Chief Biomedical Scientist for the East of England Health Protection Agency based at Broomfield Hospital in Essex, and David Stokley, Quality Manager of the Microbiology Department of the Norfolk and Norwich University Hospital, respectively, for the laboratory testing and analysis of all of the water samples.

1. Pankhurst $C$ L. Risk assessment of dental unit waterline contamination. Prim Dent Care 2003; 10: 5-10.
2. Mills S E. The dental unit waterline controversy: defusing the myths, defining the solutions. J Am Dent Assoc 2000; 131: 1427-1441.

3. ADA Council on Scientific Affairs. Dental unit waterlines: approaching the year 2000. J Am Dent Assoc 1999; 130: 1653-1664.

4. Pankhurst C L, Philpott-Howard J N. The environmental risk factors associated with medical and dental equipment in the transmission of Burkholderia (Pseudomonas) cepacia in cystic fibrosis patients. J Hosp Infect 1996; 32: 249-255.

5. Porter S R. Prions and dentistry. J R Soc Med 2002; 95: 178-181.

6. Anonymous. ADA statement on dental unit waterlines. J Am Dent Assoc 1996; 127: 185-186.

7. Kohn W G, Collins A S, Cleveland J L et al. Guidelines for infection control in dental health-care settings - 2003. MMWR Recomm Rep 2003; 52(RR-17): 1-61.

8. US Environmental Protection Agency. National Primary Drinking Water Regulations. Drinking water contaminants. http://www.epa.gov/ safewater/contaminants/index.html (accessed 20 August 2010).

9. American Dental Association. Statement on infection control in dentistry. Chicago: ADA, 2004. http://www.ada.org/1857.aspx.

10. American Dental Association. Statement on dental unit waterlines. Chicago: ADA, 2004. http://www.ada.org/1856.aspx.

11. Anonymous. Council directive $98 / 83 /$ EC of 3 November 1998 on the quality of water intended for human consumption. Off J Eur Commun 1998; L330: 32-54.

12. Walker J T, Bradshaw D J, Bennett A M, Fulford M R Martin M V, Marsh P. Microbial biofilm formation and contamination of dental-unit water systems in general dental practice. App/ Environ Microbiol 2000; 66: 3363-3367.

13. Walker J T, Bradshaw D J, Finney $M$ et al. Microbiological evaluation of dental unit water systems in general dental practice in Europe. Eur J Oral Sci 2004; 112: 412-418.

14. Schel A J, Marsh P D, Bradshaw D J et al. Comparison of the efficacies of disinfectants to control microbial contamination in dental unit water systems in general dental practices across the European Union. Appl Eviron Microbio/ 2006; 72: 1380-1387.

15. Smith A J, McHugh S, McCormick L, Stansfield R, McMillan A, Hood J. A cross sectional study of water quality from dental unit water lines in dental practices in the West of Scotland. Br Dent J 2002; 193: 645-648.

16. Tuttlebee $\mathrm{C} \mathrm{M}, \mathrm{O}^{\prime}$ Donnell $\mathrm{M} J$, Keane $\mathrm{C} T$ et al. Effective control of dental chair unit waterline biofilm and marked reduction of bacterial contamination of output water using two peroxide-based disinfectants. J Hosp Infect 2002; 52: 192-205.

17. Pankhurst C L, Coulter W, Philpott-Howard J N, Surman-Lee S, Warburton F, Challacombe S J. Evaluation of the potential risk of occupational asthma in dentists exposed to contaminated dental unit waterlines. Prim Dent Care 2005; 12: 53-59.

18. Shearer B G. Biofilm and the dental office. J Am Dent Assoc 1996; 127: 181-189.

19. Pankhurst $C$ L, Johnson N W, Woods R G. Microbial contamination of dental unit waterlines: the scientific argument. Int Dent J 1998; 48: 359-368.

20. Martin M V. The significance of the bacterial contamination of dental unit water systems. BrDent J 1987; 163: 152-154.

21. Schulze-Robbecke R, Feldmann $C$, Fischeder $R$, Janning B, Exner M, Wahl G. Dental units: an environmental study of sources of potentially pathogenic mycobacteria. Tuber Lung Dis 1995 76: 318-323.

22. Lohr D C, Goeken J A, Doty D B, Donta S T. Mycobacterium gordonae infection of a prosthetic aortic valve. JAMA 1978; 239: 1528-1530.

23. Wallace R J, Swenson J M, Silcox V A, Good R C, Tschen J A, Stone M S. Spectrum of disease due to rapidly growing mycobacteria. Rev Infect Dis 1983; 5: $657-777$.

24. Pankhurst C L, Coulter W, Philpott-Howard J N et al. 
Prevalence of legionella waterline contamination and Legionella pneumophila antibodies in general dental practitioners in London and rural Northern Ireland. Br Dent J 2003; 195: 591-594.

25. Atlas R M, Williams J F, Huntington M K. Legionella contamination of dental unit waters. App/ Environ Microbiol 1995; 61: 1208-1213

26. Williams H N, Paszko-Kolva C, Shahamat M, Palmer C, Pettis C, Kelley J. Molecular techniques reveal high prevalence of Legionella in dental units. J Am Dent Assoc 1996; 127: 1188-1193.

27. Zanetti F, Stampi S, De-Lucha G et al. Water characteristics associated with the occurence of Legionella pneumophila in dental units. Eur J Oral Sci 2000; 108: 22-28.

28. Challacombe S J, Fernandes L L. Detecting Legionella pneumophila in water systems: a comparison of various dental units. J Am Dent Assoc 1995; 126: 603-608.

29. Fotos P G, Westfall H N, Synder I, Miller R W, Mutchler B M. Prevalence of Legionella-specific $\lg \mathrm{G}$ and $\lg \mathrm{M}$ antibody in a dental clinic population. J Dent Res 1985; 64: 1382-1385.

30. Reinthaler F F, Mascher F, Stunzner D. Serolgical examinations for antibodies against Legionella species in dental personnel. J Dent Res 1988; 67: 942-943.

31. Fulford M R, Walker J T, Martin M V, Marsh P D. Total viable counts, ATP, and endotoxin levels as potential markers of microbial contamination of dental unit water systems. Br Dent J 2004; 196: 157-159.

32. Martin M V , Gallagher M A. An investigation of the efficacy of super-oxidised (Optident / Sterilox) water for the disinfection of dental unit water lines. Br Dent J 2005; 198: 353-354.

33. Anonymous. The microbiology of water. Part 1 drinking water. pp 1-127. London: HMSO, 1994.

34. Smith A J, McHugh S, Aitken I, Hood J. Evaluation of the efficacy of Alpron disinfectant for dental unit water lines. Br Dent J 2002; 193: 593-596.

35. Health Protection Agency. Enumeration of coliform bacteria and Escherichia coli by membrane filtration. National Standard Method W2, Issue 3. London: Health Protection Agency, 2004. www.hpa-standardmethods.org.uk/pdf_sops.asp.

36. Kettering J D, Munoz-Viveros C A, Stephens J A, Naylor W P, Zhang W. Reducing bacterial counts in dental unit waterlines: distilled water vs. antimicrobial agents. J Calif Dent Assoc 2002; 30: 735-741.

37. Kettering J D, Stephens J A, Munoz-Viveros C A, Naylor W P. Reducing bacterial counts in dental unit waterlines: tap water versus distilled water. J Contemp Dent Pract 2002; 15: 1-9.

38. Cobb C M, Martel CR, McKnight S A, Pasley-Mowry C, Ferguson B L, Williams K. How does time-dependent dental unit waterline flushing affect planktonic bacteria levels? J Dent Educ 2002; 66: 549-555.

39. Fiehn N, Larsen T. The effect of drying dental unit waterline biofilms on the bacterial load of dental unit water. Int Dent J 2002; 52: 251-254.

40. Walker J T, Bradshaw D J, Fulford M R, Marsh P D. Microbiological evaluation of a range of disinfectant products to control mixed-species biofilm contamination in a laboratory model of a dental unit water system. App/ Environ Microbiol 2003; 69: 3327-3332.

41. Santiago J I, Huntington M K, Johnston A M, Quinn R S, Williams J F. Microbial contamination of denta unit waterlines: Short- and long-term effects of flushing. Gen Dent 1994; 48: 528-535.

42. Williams $\mathrm{H} N$, Quinby $\mathrm{H}$, Romberg $\mathrm{E}$. Evaluation and use of a low nutrient medium and reduced incubation temperature to study bacterial contamination in the water supply of dental units. Can J Microbiol 1994; 40: 127-131.

43. Chate R A C. An audit improves the quality of wate within the dental unit water lines of three separate facilities of a United Kingdom NHS Trust. Br Dent J 2006; 201: 565-569.

44. Anonymous. Legionnaires' disease: A guide for employers. pp 1-9. Sudbury: Health and Safety Executive, 2001.

45. Croser D. Water: navigating the clinical issues. Riskwise UK Dent Protect 2005; 28: 6-7.

46. Nunn J H. Special care dentistry - a new speciality. In Hancocks S (ed) Word of mouth. Dental health E practice 2006. pp 120-124. London: Atalink Ltd, on behalf of the British Dental Health Foundation, 2005. 